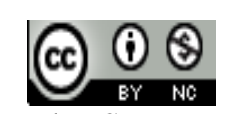

Jurnal Pendidikan Bahasa dan Sastra Indonesia is licensed under

A Creative Commons Attribution-Non Commercial 4.0 International License

\title{
Nilai Keberanian dalam Novel Negeri di Ujung Tanduk Karya Tere Liye
}

\author{
Al Ashadi Alimin ${ }^{1)}$, Saptiana Sulastri ${ }^{2)}$ \\ 1. Program Studi Pendidikan Bahasa dan Satra Indonesia, Fakultas Pendidikan Bahasa dan Seni IKIP PGRI Pontianak \\ E-mail: ashadi.alimin@merahputih.id \\ 2. Program Studi Pendidikan Bahasa dan Satra Indonesia, Fakultas Pendidikan Bahasa dan Seni IKIP PGRI Pontianak \\ E-mail: saptianasulastri@ikippgriptk.ac.id
}

\begin{abstract}
Abstrak. Penelitian ini bertujuan untuk mendeskripsikan nilai keberanian dalam novel Negeri di Ujung Tanduk karya Tere Liye. Penelitian ini menggunakan metode deskriptif, dengan bentuk kualitatif. Teknik pengumpulan data menggunakan studi dokumenter, dengan menelaah karya sastra. Penelaahan dilakukan dengan cara mengklasifikasikan bagian-bagian yang menjadi objek penelitian, khususnya nilai keberanian. Alat pengumpul data yang digunakan adalah manusia, peneliti sendiri sebagai instrumen utama. Teknik analisis data dalam penelitian ini adalah analisis isi. Hasil penelitian menunjukkan nilai keberanian meliputi: (1) nilai keberanian dalam bertarung, (2) nilai keberanian dalam menghadapi tantangan, (3) nilai keberanian dalam memperjuangkan kebenaran, (4) nilai keberanian melawan musuh, (5) nilai keberanian menyelamatkan diri dari musuh, (6) nilai keberanian menyelamatkan orang lain, (7) nilai keberanian mencari bukti kebenaran.
\end{abstract}

Kata Kunci: nilai keberanian; novel Negeri di Ujung Tanduk

\section{PENDAHULUAN}

Sastra berbicara tentang hidup dan kehidupan, tentang berbagai persoalan hidup manusia, tentang kehidupan di sekitar manusia, tentang kehidupan pada umumnya, yang semuanya diungkapkan dengan cara dan bahasa yang khas. Artinya, baik cara pengungkapkan maupun bahasa yang dipergunakan untuk mengungkapkan berbagai persoalan hidup, atau biasa disebut gagasan, adalah khas sastra, khas dalam pengertian lain daripada yang lain. Artinya, pengungkapkan dalam bahasa sastra berbeda dengan cara-cara prngungkapan yang telah menjadi biasa, lazim, atau yang itu-itu saja. Dalam bahasa sastra terkandung unsur dan tujuan keindahan. Bahasa sastra lebih bernuansa keindahan dari pada keoraktisan (Nurgiyantoro, 2010:2-3).

Penelitian sastra memiliki peranan penting dalam berbagai aspek kehidupan manusia, di samping juga berpengaruh positif terhadap pembinaan dan pengembangan sastra itu sendiri. Karya sastra dapat memberikan manfaat bagi pengarang itu sendiri dan juga pembacanya. Di dalam sebuah karya sastra pengarang dapat mengekspresikan segala perasaan, ide-ide, dan konsep-konsep nilai luhur, keyakinan serta nilai estetis yang kemudian ia tuangkan ke dalam karya sastra.

Karya sastra dapat memberikan manfaat bagi pengarang itu sendiri dan juga pembacanya. Di dalam sebuah karya sastra pengarang dapat mengekspresikan segala perasaan, ide-ide, dan konsep-konsep nilai luhur, keyakinan serta nilai estetis yang kemudian ia tuangkan ke dalam karya sastra (Sulastri dan Alimin, 2017:158)

Penelitian sastra merupakan usaha pencarian pengetahuan dan pemberimaknaan terhadap karya sastra. Sastra juga dapat menjadi sarana bagi siswa untuk belajar, hal ini sependapat dengan (Teuuw, 2015:20) yang mengatakan bahwa sastra berarti alat untuk mengajar, buku petunjuk, buku instruksi atau pengajaran

Pengkajian karya sastra dapat dilakukan dengan banyak cara diantara metode yang dapat digunakan untuk mengkaji karya sastra adalah melalui pendekatan sosiologi sastra. Penelitian ini menggunakan pendekatan sosiologi sastra. Sosiologi sastra adalah ilmu tentang pemahaman terhadap karya sastra yang disertai masyarakat. Konsep sosiologi sastra digunakan karena didasarkan pada pandangan bahwa karya sastra ditulis oleh pengarang dalam kehidupan sosial masyarakatnya. Sosiologi sastra memandang di antara genre karya sastra, yaitu genre prosa, genre puisi, dan genre drama, maka gendre prosa lah, khususnya novel yang dianggap dominan dalam menampilkan unsur-unsur sosial yang berupa nilai-nilai.

Novel merupakan bagian dari karya sastra. Novel adalah karya sastra yang dibangun oleh dua unsur yaitu unsur intrinsik dan unsur ekstrinsik.Peneliti memilih novel ada dua hal yaitu pertama, novel merupakan bentuk karya sastra yang paling popular di dunia. Bentuk karya sastra ini banyak beredar, hal ini disebabkan daya komunikasinya yang luas pada masyarakat serta fungsinya selain untuk 
menghibur juga untuk mendidik dan memberi teladan bagi kehidupan sosial yang nyata. Kedua, di dalam sebuah novel selalu mengandung pengalaman berharga yang bisa menginspirasi dan memotivasi pembaca melalui rangkaian kata-kata yang membangun sebuah cerita yang kaya akan nilai-nilai kehidupan.

Satu di antara novel yang peneliti angkat yaitu novel Negeri di Ujung Tanduk Karya Tere Liye. Alasan peneliti memilih novel Negeri di Ujung Tanduk karena novel ini cukup mendidik, bagus untuk dibaca oleh semua kalangan. Membuat pembaca menjadi berpikir dalam menghadapi kehidupan kita sebagai manusia harus selalu berjuang dan pantang menyerah dalam menghadapi hal apapun.

Nilai itu pada hakikatnya sifat atau kualitas yang melekat pada suatu objek, bukan objek itu sendiri. Sesuatu yang mengandung nilai itu artinya ada sifat atau kualitas yang melekat pada sesuatu itu. Nilai adalah sesuatu kenyataan yang tersembunyi di balik kenyataan-kenyataan lainnya. Sejalan dengan hal ini, Nilai memengaruhi sikap, pendapat, dan pandangan individu yang selanjutna tercermin dalam cara bertindak dan bertingkah laku dalam memberikan penilaian Ngalim Purwanto (Zakiyah dkk, 2014:14). Sedangkan, (Winarno, 2012:39). Mengatakan nilai adalah sesuatu yang dinilai positif, dihargai, dipelihara, diagungkan, dihormati, membuat orang gembira, puas, atau bersyukur.

Peneliti memilih nilai keberanian melihat manfaat besar sebab keberanian yang dimaksudkan ini adalah keberanian yang berdasar pada kebenaran dan dibentuk dengan penuh pertimbangan, bukan keberanian dalam arti siap melawan atau menantang siapa saja tanpa memedulikan berada di pihak yang benar atau salah. Bukan pula berani dalam pengertian memperturutkan hawa nafsu.

Konsep keberanian secara umum adalah sifat yang gagah berani, tidak pernah takut dan gentar menghadapi tantangan. Dalam perspektif positif, keberanian ditujukan untuk membela kebenaran. Keberanian adalah suatu tindakan memperjuangkan sesuatu yang dianggap penting dan mampu menghadapi segala sesuatu yang dapat menghalanginya karena percaya kebenarannya. Keberanian adalah suatu sifat mempertahankan dan memperjuangkan apa yang dianggap benar dengan menghadapi segala bentuk bahaya, kesulitan, kesakitan, dan lain-lain. Budiyono mengatakan (2007:80) keberanian adalah kualitas jiwa yang tidak mengenal rasa takut pada kritik, tetapi membuat orang melanjutkannya dengan ketenangan dan ketabahan dalam menghadapinya. Adapun ciri-ciri yang terdapat dalam keberanian, yaitu: 1) jiwa besar, 2) pantang ketakutan, 3) ketenangan, 4) keuletan, 5) kesabaran, 6) murah hati, 7) menahan diri, 8) keperkasaan, 9) memiliki daya tahan yang kuat atau senang bekerja keras.

Selanjutnya, Budiyono (2007:81) mengemukakan enam hal yang disebut pemberani sebagai berikut. (1) Dalam soal kebaikan, ia memandang ringan terhadap sesuatu yang hakikatnya berat, (2) Ia sabar terhadap persoalan yang menakutkan, (3) Memandang ringan terhadap sesuatu yang umumnya dianggap berat oleh orang lain, sehingga ia rela mati dalam memilih persoalan yang paling utama, (4) Tidak bersedih terhadap sesuatu yang tidak dapat dicapainya, (5) Tidak gundah apabila menerima berbagai cobaan, (6) Kalau ia marah dan mengadakan pembalasan, maka kemarahan dan pembalasannya dilakukan sesuai dengan ukuran, objek dan waktu yang diwajibkan.

Keberanian adalah tekad untuk tetap mempertahankan sikap yang telah diyakini sebagai kewajiban dan tanggung jawab, juga apabila tidak disetujui atau bahkan secara aktif dilawan oleh lingkungan. Budiyono (2007:94) menjelaskan ciri-ciri nilai keberanian, yaitu sebagai berikut: berpikir secara matang dan terukur sebelum bertindak, mampu memotivasi orang lain, selalu tahu diri, rendah hati, dan mengisi jiwa serta pikiran dengan pengetahuan baru menuju ke arah yang benar, bertindak nyata, semangat menciptakan kemajuan, siap menanggung resiko dan konsisten. Berdasarkan pendapat diatas dapat disimpulkan bahwa nilai keberanian adalah suatu perangkat keyakinan yang ditujukan pada sesuatu yang tidak mengenal rasa takut untuk mempertahankan sikap dan membela kebenaran yang merupakan kewajiban dan tanggung jawab yang harus dijalankan.

Berdasarkan paparan di atas peneliti tertarik meneliti nilai keberanian dalam novel Negeri di Ujung Tanduk karya Tere Liye yang tercermin pada tokoh yang ada dalam cerita. Diharapkan konsep nilai yang berkaitan dengan penelitian khususnya nilai keberanian dapat menjadi panutan bagi peserta didik.

\section{METODE}

Bentuk penelitian ini adalah penelitian kualitatif dengan metode yang digunakan adalah metode deskriptif kualitatif yang mengungkap keadaan sebenarnya dalam novel. Pendekatan yang digunakan pendekatan sosiologi sastra yang memfokuskan pada analisis karya sastra berdasarkan mengacu pada cara memahami dan sastra yang mempertimbangkan segi-segi kemasyarakatan (sosial). Pendekatan sosiologi sastra yaitu pendekatan terhadap sastra yang mempertimbangkan segi-segi kemasyarakatan (Wahyuningtyas dkk, 2011:24). Sedangkan, Ratna (2004:339-340) menjelaskan bahwa dalam pertimbangan sosiologi sastra adalah analisis karya sastra dalam kaitannya dengan masyarakat, maka model analisis yang dapat dilakukan meliputi tiga macam, yaitu (1) menganalisis masalah-masalah sosial Yng terkandung di dalam karya sastra itu sendiri, kemudian menghubungkannya dengan kenyataan yang pernah terjadi. Pada umumnya disebut sebagai aspek ekstrinsik, model hubungan yang terjadi disebut refleksi, (2) sama dengan di atas, tetapi dengan cara menemukan hubungan antarstruktur, bukan aspek-aspek tertentu, dengan model hubungan yang bersifat dialektika, (3) menganalisis karya sastra dengan tujuan untuk memperoleh informasi tertentu, dilakukan oleh disiplin tertentu. Model analisis inilah yang pada umumnya menghasilkan penelitian karya sastra sebagai gejala kedua.

Data dalam penelitian ini adalah kutipan berupa narasi dan dialog yang berhubungan dengan nilai keberanian 
yang terdapat dalam novel Negeri di Ujung Tanduk karya Tere Liye. Teknik pengumpulan data menggunakan teknik studi dokumenter. Arikunto (2006:101) menyatakan teknik studi dokumenter adalah teknik dengan cara mengumpulkan data yang dilakukan dengan kategorisasi dan klasifikasi bahan-bahan tertulis yang berhubungan dengan masalah penelitian, baik dari sumber dokumen maupun buku-buku, koran dan majalah dengan mencatat dokumen maupun arsip yang berkaitan dengan masalah dan tujuan penelitian. Pencatatan dilakukan dengan menggunakan kartu data untuk memudahkan pengelompokkan data-data yang dibutuhkan. Pencatatan ini bertujuan untuk mendapatkan informasi yang mendukung analisis dan interpretasi data.

Teknik pemeriksaan keabsahan data menurut Sutopo (2002:78) mengemukakan bahwa validitas data adalah kesahihan data penelitian. Penelitian ini menggunakan triangulasi data untuk mengumpulkan data yang sama. Artinya data yang sama atau sejenis akan lebih mantap kebenarannya bila digali dari beberapa sumber data yang berbeda. Moleong (2007:280) mengatakan analisis data adalah proses mengorganisasikan dan mengurutkan data ke dalam pola, kategori dan satuan uraian dasar sehingga dapat ditemukan tema dan dapat dirumuskan hipotesis kerja seperti yang disarankan oleh data. Adapun teknik analisis data dalam penelitian ini adalah analisis isi. Webber (Satori, 2013:157) menyatakan bahwa kajian isi adalah metodologi yang memanfaatkan seperangkat prosedur untuk menarik kesimpulan dari sebuah buku atau dokumen. Dalam penelitian ini teknik analisis datanya yakni dengan mendeskripsikan secara objektif dan sistematis tentang manifestasi komunikasi melalui sebuah buku atau dokumen.

\section{HASIL DAN PEMBAHASAN}

HASIL

Pada novel Negeri di Ujung Tanduk ditemukan beberapa hasil penelitian yang sesuai dengan fokus penelitian meliputi (1) nilai keberanian dalam bertarung, (2) nilai keberanian dalam menghadapi tantangan, (3) nilai keberanian dalam memperjuangkan kebenaran, (4) nilai keberanian melawan musuh, (5) nilai keberanian menyelamatkan diri dari musuh, (6) nilai keberanian menyelamatkan orang lain, (7) nilai keberanian mencari bukti kebenaran

Keberanian adalah sifat yang gagah berani, tidak pernah takut dan gentar menghadapi tantangan. Dalam perspektif positif, keberanian ditujukan untuk membela kebenaran. Keberanian adalah kualitas jiwa yang tidak mengenal rasa takut pada kritik, tetapi membuat orang melanjutkannya dengan ketenangan dan ketabahan dalam menghadapinya.

Nilai Keberanian dalam Bertarung

Berdasarkan analisis yang dilakukan oleh peneliti, di dalam novel Negeri Di Ujung Tanduk karya Tere Liye terdapat kutipan-kutipan yang menggambarkan nilai keberanian pada diri tokoh. Hal ini berkaitan langsung dengan para tokoh dalam menjalani kehidupan.
"Dua petarung sedang jual-beli pukulan di tengah ruangan, bertinju. Arena pertandingan tanpa ring pemisah apalagi rangkep tertutup. (Tere Liye, 2013:9).

Kutipan di atas menunjukan bahwa adanya nilai keberanian yang di miliki oleh para petarung dalam mengikuti petarungan. Pertarungan tersebut membuat Thomas cemas ketika melihat lawan pertamanya dibuat tersungkur oleh petarung yang satunya. Pertarungan tersebut yang membuat Thomas mencemaskan dirinya ketika melihat pemenang petarung yang disebut Monster tersebut begitu tenang saat beradu pukulan untuk mengalahkan musuhnya bahkan dia bisa melihat pukulan-pukulan lawannya datang dan memilih pukulan balasan paling masuk akal untuk membalas pukulan dengan gerakan yang amat efesien. Thomas menggeleng, dan mengatakan dia petarung sejati tidak ada monster seperti itu, dan jelas sebutan monster tidak cocok dengan wajahnya yang bersih dan bersahabat. Sebutan itu hanya cocok dengan betapa dinginnya dia menghabisi lawan-lawannya kata Thomas. Melihat sang juara tetap bertahan, membuat Thomas tetap berani ingin mengikuti pertarungan yang akan dilaksankan di Jakarta pada saat dia bertarung nanti dengan lawan tarungnya yang di sebut monster tersebut. Pada kutipan di atas menunjukkan sifat yang gagah berani dan tidak pernah takut dalam menghadapi tantangan.

Nilai Keberanian dalam Menghadapi Tantangan

"Kau tidak akan berubah pikiran, bukan? sebuah tangan menyikut lenganku, berkata kencang, berusaha mengalahkan bising. Aku menoleh, menatap wajah menyebalkan di sebelahku. Maksudku jika kau mau, aku masih bisa membatalkan pertarungan. "Aku tidak akan membatalkan pertarungan", aku menyergah Theo memotong kalimatnya, "simpan omong kosongmu!". (Tere Liye, 2013:11)

Kutipan di atas menunjukan bahwa Thomas memang memiliki sifat yang berani dan tidak pernah takut dalam menghadapi tantangan. Thomas tidak akan membatalkan pertarungannya setelah mendengarkan perkataan Theo sahabatnya yang melemahkan semangatnya. Kata "Aku tidak akan membatalkan pertarungan" dalam kutipan tersebut mencerminkan Thomas sangat berani untuk mengikut pertarungan tersebut, walaupun lawannya dijuluki dengan sebutan monster. Sebagai petarung sejati Thomas tidak akan mundur dan terpengaruh oleh perkataan temannya. Kata "Simpan omong kosongmu!" dalam kutipan itu dengan tegas diucapkan oleh Thomas kepada Theo untuk menunjukkan bahwa Thomas siap untuk bertarung.

Nilai Keberanian dalam Memperjuangkan Kebenaran

"Hadirin, aku mengangkat tangan, memasang intonasi suara serius dan bertenaga, maafkan saya, tapi saya akan tegaskan didepan kalian semua, bahwa bagi kami, poltik tidak lebih adalah permainan terbesar dalam bisnis omong kosong, industri arti fisal penuh kosmetik yang pernah ada di dunia.(Tere Liye,2013:20)

Kutipan di atas menunjukan ada nya keberanian yang menunjukan sikap mempertahankan dan memperjuangkan apa yang di anggap benar. Kalimat tersebut di tunjukan pada 'Hadirin, aku mengangkat tangan, memasang intonasi suara 
serius dan bertenaga, maafkan saya, tapi saya akan tegaskan didepan kalian semua, bahwa bagi kami, poltik tidak lebih adalah permainan terbesar dalam bisnis omong kosong, industri arti fisal penuh kosmetik yang pernah ada di dunia' kalimat tersebut jelas sekali menunjukan bahwa keberanian seseorang yang berani mengkritik atau memberikan masukan pada acara rapat politik yang sedang berlangsung di Hong Kong, Thomas yang menghadiri rapat konferensi komunikasi politik tersebut membuat dia berani memberikan kritikan pada saat sesi tanya jawab, dan pada sesi tanya jawab Thomas selalu menyinggung berbagai pihak dengan ketidakadilan yang mereka berikan pada bawahaannya.

Thomas selalu mengatakan bahwa politik adalah permainan terbesar yang ada di dunia, karena melihat banyaknya omong kosong dan Cuma janji ketika calon kandidat ingin memenangi sebuah partai. Tetapi disinilah Thomas mengatakan bahwa dia akan selalu berusaha untuk memenangi calon kandidatnya. Thomas menyarankan temukan hal paling menarik di negara dalam bisnis omong kosong, dan sisi yang paling penting bagi pemilihan kalian seperti pemerintahan yang bersih, gerakan antikorupsi, dan dengan saran seperti itu maka kita akan menemukan jalan untuk memenangi pemilihan kata Thomas dalam memberikan ide untuk calon kandidatnya dengan tujuan agar bisa memenangi pemilihan calon presiden.

Nilai Keberanian Melawan Musuh

"Tidak ada waktu untuk berpikir, aku memutuskan menembak sebelum mereka menembaki kami. Melihat kami berempat sudah naik, belalai crean bergerak mundur. Kami keluar dari ruangan tersebut, langsung di sambut gerimis yang membungkus kota Hong Kong. (Tere Liye, 2013:91)

Kutipan di atas menunjukan bahwa keberanian Thomas dan temannya yang menembaki para petugas yang mengejar mereka di sebuah gedung tahanan, hal tersebut di lakukan nya karena mereka ingin menyelamatkan diri dari kejaran para petugas yang menahan mereka dengan kejadian di Hong Kong seperti pembahasan kutipan sebelumnya. Pada kalimat 'Tidak ada waktu untuk berpikir, aku memutuskan menembak sebelum mereka menembaki kami' dalam kutipan tersebut menunjukkan bahwa Thomas dan temannya yang ingin keluar dari ruangan tahanan, dan dengan menembak para pasukan yang ada diruangan tersebut membuat Thomas dan temannya bisa keluar dan akhirnya bisa bebas dari tahanan mereka. Sikap keberanian yang dimiliki oleh Thomas dan temannya itu membuat dia harus menembaki para anggota kepolisian agar mereka lolos dari tahanan tersebut.

Nilai Keberanian Menyelamatkan Diri dari Musuh

"Kami harus berlarian melewati anak tangga, yang juga dinding-dindingnya sudah terkelupas. Aku bergumam tidak sabaran, memaksa Maryam agar bergerak lebih cepat. Kadek sudah mengondong Opa sejak lantai delapan belas. Mereka bergerak lebih cepat dibanding aku dan Maryam. Kami harus bergegas. Tidak lebih dari lima menit, satu pasukan penuh sudah keluar mengejar dari lobi gedung di seberang, tempat kami ditahan. (Tere Liye, 2013:94)

Kutipan di atas menceritakan bahwa bagaimana keberanian Thomas dan teman-temannya yang ingin menyelamatkan diri nya dari pasukan yang mengejarnya, dan demi menyelamatkan diri nya mereka harus segera pergi sehingga berlarian melewati anak-anak tangga yang dindingnya juga sudah terkelupas dan harus bergerak lebih cepat lagi agar tidak tertangkap oleh para pasukan tersebut. Hal itu dilakukan karena mereka merasa diri nya tidak bersalah pada kejadian penuduhan membawa barang senjata dan seratus kilogram butiran putih yang ada dikapal yang mereka tumpangi dan mereka pun cuman dijebak oleh sekelompok para mafia. Hal tersebut merupakan adanya keberanian yaitu pada kalimat 'Kami harus berlarian melewati anak tangga, yang juga dinding-dindingnya sudah terkelupas. Aku bergumam tidak sabaran, memaksa Maryam agar bergerak lebih cepat.'

Nilai Keberanian Menyelamatkan Orang Lain

"Detektif Liu dengan gagah berani menerobos kepulan asap, meloncat melepaskan enam tembakan beruntun. Tiga orang roboh lagi dari pojok ruangan yang berbeda. (Tere Liye, 2013:342)

Kutipan di atas menunjukkan bahwa keberanian yang dimiliki oleh Detektif Liu yang membantu menyelamatkan Thomas dari tahanan pasukan di Hong Kong dan dengan beraninya Detektif Liu menerobos kepulan asap dan meloncat melepaskan enam tembakan yang dia lakukan.Pada kalimat "Detektif Liu dengan gagah berani menerobos kepulan asap, meloncat melepaskan enam tembakan beruntun" dalam kutipan ini menunjukkan bahwa Detektif Liu seorang anggota kepolisian dari Hong Kong yang ikut membantu Thomas dan teman yang lainnya untuk membawa Om Liem keluar dari tahanan para mafia tersebut. Usaha nya yang begitu berani yaitu yang menorobos kepulan asap yang ditembaki oleh para mafia membuat dia harus segera menolong Om Liem yang terduduk lemah di kursi plastik. Dan melihat Om Liem terkulai di atasnya, tubuhnya semangkin lemah, terlihat mengenaskan tapi dia masih bernapas membuat Detektif Liu dan anggota pasukan Rudi segera mengangkat Om Liem dan membawa Om Liem keluar. Usaha Thomas dan teman-temannya yang ingin menyelamatkan Om Liem pun akhirnya berhasil dan melihat kondisi tubuh Om Liem terkulai lemah membuat Thomas, Detektif Liu dan Rudi segera membawanya untuk melakukan perawatan yang dilakukan oleh tim medis.

Nilai Keberanian Mencari Bukti Kebenaran

"Lihatlah! Kita memiliki daftar lengkap mafia hukum yang katanya tidak kasatmata dan kebal itu. Dan soal bukti serta kesaksian, hei, kita punya amunisi untuk merontokkannya satu per satu. Lima kotak dari daftar daftar ini sudah bisa dicoret malam ini." (Tere Liye, 2013:284)

Kutipan di atas menceritakan bahwa Thomas dan teman-temannya itu mencari bukti-bukti dari para mafia hukum tersebut agar para mafia hukum itu segera dirontokkan dan diseret ke pengadilan. Pada kalimat "Lihatlah! Kita memiliki daftar lengkap mafia hukum yang katanya tidak kasatmata dan kebal itu. Dan soal bukti serta kesaksian, hei, kita punya amunisi untuk merontokkannya satu per satu" kutipan ini menunjukkan bahwa Thomas dan teman-temannya memiliki keberanian untuk mencari buktibukti yang belum diketahui dari berbagai pihak, oleh karena 
itu Thomas dan teman-temannya pun harus bekerja keras dalam mencari bukti-bukti tersebut. Dan dengan hasil kerja kerasnya selama ini pun membuat Thomas tidak sia-sia karena sudah ada beberapa bukti nama yang Thomas dapatkan dalam pelaku semua permasalahan terutama dalam tuduhan-tuduhan sebelumnya yang terjadi pada Thomas yang membuat Thomas dikejar-kejar oleh satuan kepolisian. Thomas mengatakan dengan bukti yang sudah dia dapatkan maka Thomas beramunisi ingin merontokkannya satupersatu ke pengadilan agar dapat dihukum sesuai dengan aturan undang-undang yang berlaku.

\section{SIMPULAN DAN SARAN}

\section{SIMPULAN}

Berdasarkan hasil analisis dapat disimpulkan bahwa nilai keberanian adalah sifat yang gagah berani, tidak pernah takut dan gentar menghadapi tantangan. Dalam perspektif positif, keberanian ditujukan untuk membela kebenaran. Keberanian adalah kualitas jiwa yang tidak mengenal rasa takut pada kritik, tetapi membuat orang melanjutkannya dengan ketenangan dan ketabahan dalam menghadapinya.

Adapun nilai keberanian yang terdapat dalam novel Negeri di Ujung Tanduk Karya Tere Liye meliputi: (1) nilai keberanian dalam bertarung, (2) nilai keberanian dalam menghadapi tantangan, (3) nilai keberanian dalam memperjuangkan kebenaran, (4) nilai keberanian melawan musuh, (5) nilai keberanian menyelamatkan diri dari musuh, (6) nilai keberanian menyelamatkan orang lain, (7) nilai keberanian mencari bukti kebenaran.

\section{DAFTAR PUSTAKA}

Arikunto, S. (2006). Prosedur Penelitian, Suatu Pendekatan Praktik. Jakarta: Pt Rineka Cipta.
Budiyono, Kabul. (2007). Nilai-nilai Kepribadian dan kejuangan Bangsa Indonesia. Cetakan Perdana. Bandung: Alfabeta

Moleong, L. J. (2014). Metodologi Penelitian Kualitataif. Bandung: Pt Remaja Rosdakarya

Nurgiyantoro, B. (2013). Teori Pengkajian Fiksi. Yogyakarta: Gajah Mada University Press.

Ratna, Nyoman Kutha. (2004). Teori, Metode, Teknik Penelitian Sastra.Yogyakarta: Pustaka Pelajar

Satori, D., \& Komariah, A. (2013). Metodologi Penelitian Kualitatif. Bandung: Alfabeta.

Sulastri, S. (2017). NILAI PENDIDIKAN KARAKTER KERJA KERAS DALAM NOVEL 2 KARYA DONNY DHIRGANTORO. Jurnal Pendidikan Bahasa, 6(2), 156-168.

Teuuw. A. (2015). Sastra dan ilmu Sastra. Bandung: Pustaka Jaya.

Winarno. (2012). Pendidikan Pancasila Di Perguruan Tinggi. Surakarta: Yuma Pustaka.

Wahyuningtyas. dkk. (2010). Pengantar Apresiasi Prosa. Surakarta: Yuma Pustaka.

Zakiyah, dkk. (2014). Pendidikan Nilai: Kajian Teori dan Praktik di Sekolah. Bandung: Pustaka Setia. 